\title{
Socio-Demographic Determinants of Poverty in Nigeria and its Gender Differentials
}

\author{
Abdullahi Buba \\ Musa Abdu \\ Department of Economics, Gombe State University, Gombe-Nigeria \\ Idi Adamu \\ $\mathrm{PhD}$ candidate, Modibbo Adama University of Technology Yola-Nigeria \\ Adamu Jibir \\ $\mathrm{PhD}$ candidate, Department of Economics, University of Colombo-Sri Lanka \\ Doi: 10.19044/esj.2018.v14n14p236 URL:http://dx.doi.org/10.19044/esj.2018.v14n14p236
}

\begin{abstract}
Poverty reduction is one of the greatest challenges facing international community and it is an invaluable requirement for sustainable development. This study was conducted to empirically examine the influence of socioeconomic as well as demographic variables on households' vulnerability to social exclusion or deprivation with more emphasis on gender inequality. The study employed binary probit regression analysis of poverty as well as Oaxaca-Blinder decomposition to examine factors responsible for inequality with respect to socio-economic fortunes among Nigerian households. Evidence from the study revealed that socio-demographic variables as well as labor characteristics are strong determinants of poverty in the country, and the findings confirmed to the theoretical propositions on causes of poverty. However, empirical results from the Oaxaca-Blinder decomposition show that female headed households are more disadvantaged in terms of socioeconomic deprivation than the male headed households. The study concluded by presenting concluding remarks and policy implications for policymakers toward poverty reduction in Nigeria.
\end{abstract}

Keywords: Poverty, Inequality, Oaxaca-Blinder decomposition, Nigeria

\section{Introduction}

Eradication of poverty is one of the greatest challenges bedeviling international community and it is therefore an indispensable requirement for the attainment of sustainable development (United Nations, 2015). As a result countries as well as regional and international organizations are committed toward eradication of chronic poverty and hunger such that resources and 
action plans (e.g Millennium Development Goals) are designed with a view of curbing poverty among others. This enthusiasm at the international level further led to the declaration of Sustainable Development Goals (SDGs) with well-defined targets and measurable outcomes among which is to end poverty in all its forms everywhere by 2030 (United Nations, 2015). SDGs, therefore, as noted in United Nations (2015) is a strong post-2015 development agenda that seek to complete unfinished business of MDGs, and respond to new challenges.

Thus, declaration of SDGs is commendable as performance by developing countries of Asia, Latin America, and Africa in eradicating poverty is discouraging and pathetic despite appreciable growth recorded in such economies (see Collier, 2007). This became pertinent as the proportion of those living in extreme poverty has been on the rise, despite decline in poverty rate in Sub-Saharan Africa as noted by Maku, Ogwumike, \&Adesoye, (2014) and specifically in Nigeria for example, although poverty rate remains relatively stable but the situation worsened after implementation of MDGs as documented by Abdullahi, (2014). In view of that there is an urgent need in Nigeria for holistic effort toward attainment of inclusive growth and equitable distribution of resources which would impact positively on wellbeing of the masses (Dollar \&Kraay, 2002) and reduce the proportion of Nigerian population living in poverty. This can only be achieved by examining the root causes of poverty among Nigerian households with specific focus on gender differentials thereby drawing roadmap that can mitigate extreme poverty and hunger in the country.

Again, previous studies on poverty like Fields, (1989); Hunte, (1997); Christiaensen, Demery, \& Paternostro, (2003); Chaudhry, Malik, \& Ashraf, (2006); SESRTCIC, (2007); and Stephen \& Simoen, (2013) centered on economic growth, or income per capita and consumption expenditure as proxies of poverty. Consequently, studies on poverty based on economic growth, income per head, or consumption expenditure have inherently failed to account for broader social exclusion and deprivation in resource control among households. Thus, to examine poverty as social exclusion studies like Shirazi, (1995); Anyanwu, (2010); and Deressa, (2013) used Household Income and Expenditure Survey (HIES), National Integrated Survey of Households (NISH), and Household Income, Consumption and Expenditure Survey (HICES) datasets to examine households vulnerability to poverty. In line with the above, therefore, this study set out to examine factors that contribute to the likelihood of households being exposed to poverty in Nigeria using 2013 Demographic and Health Survey dataset which allowed for documenting a broader analysis of socio-economic inequality among households in Nigeria. 
The paper is structured in to five sections. Following this introduction is literature review and methodological techniques presented in sections two and three respectively. Presentation and discussion of results is presented in section four while section five presents conclusions and policy implications.

\section{Theoretical consideration and Review of related Literature The Concept of Poverty}

The meaning of poverty is one of the issues that has generated intense debate among experts and researchers in Development Economics and such debate tends to be overshadowed by researchers' socio-cultural, ethical, political, or ideological orientation, and norms and conventions of his/her community, institution, or organization (Iyenda, 2007). For instance, poverty is considered as an inadequacy of financial resources or low level of income by a household, or group of people, or individual to meet basic needs of life (Dasgupta, 1982; and Mowafi\& Khawaja, 2005). This definition can be linked to poverty line where it can either be relative or absolute. In a contemporary world, poverty is being regarded as a social exclusion rather than a narrowed and strict definition as economic phenomenon (Skalli, 2001). Thus, from social exclusion perspective, poverty is a multidimensional phenomenon in which not only economic forces, rather, interaction of both demographic and socio-cultural forces result in an insufficiency or deficiency of physical necessities, assets and income (Chambers, 1995; Skalli, 2001; and Todaro\& Smith, 2011). In view of the above, this study is situated within the boundaries of multidimensional perspective of poverty.

\section{Causes of Poverty}

The factors responsible for household vulnerability to poverty differ from economy to another and in different points in time. Causes of poverty in urban areas, to McNamara (1975), include unemployment, unorganized informal sector and immigration. Existence of racial and gender discrimination among labor in an industry, disappearance of key labor employer, and increase in destitution are responsible for manifestation of acute poverty (Kodras, 1997). Neilson, Contreras, Cooper, \& Hermann (2008) observed that the factors responsible forhousehold exposure to poverty include labor instability, lack of proper health insurance, poor access to quality education, and uncertainty about social security programmes.

However, causes of poverty in Nigeria include low per capita income, poor education system, and social discrimination (Ucha, 2010; and Ijaiya, Ijaiya, Bello, \&Ajayi, 2011). We therefore, underpinned this study to ascertain influence of certain demographic factors, labor characteristics, and social forces on likelihood of households' vulnerability to chronic poverty and our chosen variables are within the purview of theoretical assumptions on causes 
of poverty like genetic theory, human capital theory, and psycho-social perspective as expounded by Adeola (2005).

\section{Measurement of Poverty}

Traditionally a threshold used in measuring poverty centered on income and/or expenditures by households (see Foster, Greer, \& Thorbecke, 1984; Mowafi \& Khawaja, 2005; Figini \& Santarelli, 2006; and Iyenda, 2007). Nevertheless, obtainable practice by development agencies and international donor institutions measure livelihood of people in terms of human capital development as argued by SESRTCIC (2007) and such approach include variables like life expectancy, adult literacy rate, and gross enrollment ratio. In order to measure poverty among Nigerian households this study used wealth index constructed in the DHS which indicate inequalities in households' characteristics in relation to use of health and other basic services, and health outcome (see national Population Commission and ICF International, 2014).

\section{Theoretical Perspective}

This study adapts deprivation trap theory of poverty pioneered by Chambers. According to the theory, the poor is trapped in a circle of poverty referred to the deprivation trap. Deprivation according to Chambers (1995) refers to lacking what is needed for well-being. This deprivation, therefore, includes lack of basic means of necessities by an individual or households which contributes to physical weakness in form of lack of food, malnutrition, and inability to settle health bills; to isolation as a result of inability to pay education bills, to buy radio, or bicycle; to vulnerability due to failure to meet exigencies; and to powerlessness because of lack of wealth goes with low esteem or status, hence the poor have no voice as further explained by Chambers. Thus, deprivation trap of poverty adequately helps in expatiating the variants of poverty among households in Nigeria as it captured the methodology used in determining household's tendency of being poor or otherwise.

\section{Empirical Literature}

There are plethoras of empirical studies over the years that investigated poverty and its related concepts with various form of conclusion regarding its meaning, causes and effect among countries particularly developing economies. For instance, Thurow (1967) examined the causes of poverty in Alaska and Hawaii. Evidence from the study indicates that proportion of families living with poverty has been positively and significantly determined by families depending on faming, families who have no one in the labor force, and families whose head has less than 8 years of schooling, and families 
headed by a nonwhite at 1 percent and 5 percent respectively. Whereas, negative and significant effects has been found between families living with poverty and proportion of full time workers, industrial structure of a state, and families living in Alaska. The paper concludes that massive investment in human capital, opportunities for nonwhite (Negros), and effort toward full employment can significantly reduce the number of families living in poverty in lines.

Neilson, Contreras, Cooper and Hermann (2008) carried out an empirical analysis of poverty dynamics in Chile. The study used transition matrix analysis using 1996-2001 National Socioeconomic Survey dataset to determine absolute mobility with respect to entering and exiting poverty. Result of the transition matrix shows that 54.4 percent of poor households in 1996 exit from poverty by the year 2001. Also, 11.4 percent of households which were not poor in 1996 became poor in 2001. Further evidence from the study indicated that labor dynamics is the major factor inducing entry to or exit from poverty, whereas, demographic factors and other sources of income are found not to be very significant.

Figini and Santarelli (2006) conducted a panel analysis of the impact of globalization on poverty. The study measured determinants of both absolute and relative poverty separately and diverse evidence was found in both cases. Specifically, results of their study reveal that trade openness and size of the government have strong negative and significant impact on absolute poverty, while, financial openness has positive influence on absolute poverty but not statistically significant. Conclusively, they concluded that the substantial difference between results obtained from absolute and relative poverty analysis is consistent with argument that absolute and relative poverty are two separate concepts.

Guiga and Rejeb (2012) carried out a panel study consisting 52 developing countries covering the period 1990-2005 to examine the major causes of poverty reduction. Estimates from the model show that increase income per head, increase in secondary school enrollment, and logarithm of Gini coefficient lead to decrease in poverty rate. Whereas, inflation rate is found to has no statistical influence on poverty reduction. The study concludes that inclusive growth is crucial for poverty reduction by increasing income of the poor.

Shirazi (1995) evaluated determinants of poverty in Pakistan. The study used Household Income and Expenditure Survey (1987-1988) dataset and logistic regression analysis was conducted. Findings from the study indicate that increase transfer of Sadaqat, and increase educational attainments have less likelihood of a household becoming poor. Increase number of household size, and households residing in Punjab province have more tendencies of being poor. 
Chaudhry and Rahman (2009) put forward an empirical analysis of gender inequality in education and its impact on rural poverty in Pakistan using survey data. Empirical findings from the study indicate that household size and female-male ratio have more probabilities of being poor. While, female-male enrollment ratio female-male literacy ratio, female-male ratio of total years of schooling, female-male ratio of earners, and education level of household head have significant negative probability on rural poverty.

Achia, Wangombe, and Khadioli (2010) conducted a logistic regression analysis to identify determinants of poverty in Kenya using Demographic and Health Survey (2003). Evidence from the study revealed that province located further from Nairobi, household headed by a protestant, household headed by a Muslim, rural communities, and ethnicity are significant factors explaining distribution of poverty in Kenya.

Sakuhuni, Chidoko, Dhoro and Gwaiudepi (2011) looked at the determinants of poverty in Zimbabwe using cross sectional data for 2005. Results from the study show that age of household head, and household size have significant and positively influence chances of becoming poor. Age square, household headed by male, marital status, level of education, employment (except informal sector), number of sources of income, credit availability, and land area cultivated have negative and significant influence on likelihood of being poor.

Deressa (2013) conducted a logistic regression analysis of household vulnerability to poverty in rural Oromiya of Ethiopia. Data used for the study is based on the 2004/2005 Household Income, Consumption and Expenditure Survey (HICES) and Welfare Monitoring Survey (WMS). Evidence from the study reveal that, age of household head, household size, and illiterate household head have positive and significant influence on household chances of being vulnerable to poverty. While household size square, has negative and significant influence on chances of household being vulnerable to poverty.

Anyanwu (2010) studied determinants of gendered poverty in Nigeria using 1996 National Consumer Survey dataset. Empirical evidence from female headed household model suggests that age of the household head and her level of education have negative probabilities of being poor. Households residing in rural areas, north central, working in manufacturing sector, household size and age square have positive probabilities of being poor.

Ijaiya et al (2011) examined the role of economic growth on poverty reduction in Nigeria. Evidence from the multiple regression analysis conducted portrays that initial level of growth has negative and non-significant effect on poverty reduction and changes in growth has positive and significant influence on poverty reduction. The study concludes by recommending that sustainable macroeconomic policies, increases investment in infrastructures 
and good governance would go a long way in search for long run increase growth and poverty reduction in the country.

From above studies reviewed, it is evident that less or no attention was paid to diverse socio-demographic variables, labor characteristics, and gender disparity in terms of socio-economic inequality with reference to Nigeria. Therefore, this study fills the gap.

\section{Methodology}

\section{Sources of Data}

This study used 2013 Demographic and Health Survey (DHS) for Nigeria. The survey was conducted by National Population Commission (NPC) and ICF International (2014) which covered the entire population residing in non-institutional dwellings units in the country. The survey adopted cluster sampling frame of Enumeration Areas (EAs) used for 2006 population census in Nigeria. The dataset was selected using a stratified threestage cluster design comprising a total of 904 clusters, 372 in urban areas and 532 in rural areas and a sample of 40,680 households were randomly selected for the survey.

\section{Model Specification}

To achieve the specific objectives raise in section one of this paper, the following model was specified:

$$
\begin{aligned}
\log \left(\frac{\text { Poor }_{i}}{1-\text { Poor }_{i}}\right) & \\
& =\alpha+\beta_{1} \text { Demographic }_{i}+\beta_{2} \text { Labour }_{i}+\beta_{3} \text { Socio }_{i}+\varepsilon_{i} \\
& -----------(1)
\end{aligned}
$$

Where Poor $_{\mathrm{i}}=$ a dichotomous variable indicating whether a household is poor or not.

$\alpha=$ constant term

Demographic $\mathrm{i}_{\mathrm{i}}=$ vector of demographic characteristics of households

Labor $_{i}=$ vector of labor characteristics of households

Socio $_{\mathrm{i}}=$ vector of social characteristics of households

$\varepsilon_{i}=$ error term

Table 1: Definition of Variables

\begin{tabular}{|ll|}
\hline Variables & Definitions \\
Demographic & Include demographic variables like AgeHH, HHSize, and \\
& Female \\
AgeHH & Age of Household Head \\
AgeHH2 & Age Square of Household Head \\
HHSize & Household Size \\
Female & Female Headed Household (Female=1 and Male=0) \\
Labor & Include labor characteristics like Heduc, Employment, and \\
& Literacy \\
Heduc & Highest education qualification of household head \\
\hline
\end{tabular}




\begin{tabular}{|ll|}
\hline Employment & $\begin{array}{l}\text { Household head is employed=1 otherwise }=0 \text { (either formal or } \\
\text { informal) }\end{array}$ \\
Literacy & Household head is literate $=1$ otherwise $=0$ \\
Social & Include social characteristics like NE, NC, NW, SE, SS, SW, \\
& Rural, Igbo, Hausa, Yoruba, and others. \\
NE & Household reside in north-east $=1$ otherwise $=0$ \\
$\mathbf{N C}$ & Household reside in north-central=1 otherwise $=0$ \\
$\mathbf{N W}$ & Household reside in north-west $=1$ otherwise $=0$ \\
$\mathbf{S E}$ & Household reside in south-east $=1$ otherwise $=0$ \\
$\mathbf{S S}$ & Household reside in south-south $=1$ otherwise $=0$ \\
$\mathbf{S W}$ & Household reside in south-west $=1$ otherwise $=0$ \\
Rural & Household is located in rural area $=1$ otherwise $=0$ \\
$\mathbf{I g b o}$ & Household speaks Igbo as its main language $=1$ otherwise $=0$ \\
Hausa & Household speaks Hausa as its main language $=1$ otherwise $=0$ \\
Yoruba & Household speaks Yoruba as its main language $=1$ otherwise $=0$ \\
Others & Household speaks other ethnic minority $=1$ otherwise $=0$ \\
\hline
\end{tabular}

Source: Authors' Construction

\section{Method of Data Analysis}

Both descriptive analysis (where applicable) and econometric analysis were applied in the study. Basically, descriptive statistic was used to describe household poverty distribution in Nigeria, age of household head and household size distributions. In conducting the econometric analysis, the paper used discrete choice models rather than classical regression analysis. This is because, the study entails qualitative response and the dependent variable in the model is a non-continues variable. Thus, the assumptions of conventional regression break down and consequently ordinary least square (OLS) method might not be appropriate in the analysis of such discrete choice models (Wooldridge, 2002; Baum, 2006; Cameron \& Trivedi, 2009; and Greene, 2013).

However, for the purpose of accuracy and consistency three estimates were presented and only parameters of binary model were interpreted. Also, method of Blinder-Oaxaca decomposition technique pioneered by Blinder (1973) and Oaxaca (1973) was used in analyzing gender differentials in terms of socio-economic inequality among Nigerian households.

\section{Results and Discussions}

This section of the study presents results and findings of the study. Table 2 presents frequency distribution of households that fall within poverty threshold (both relative and absolute) in Nigeria as contained in DHS 2013. 
Table 2:Households Poverty Distribution in Nigeria

\begin{tabular}{|lll|}
\hline Relative Poverty & Frequency & Percentage \\
Poorest & 6,602 & 16.95 \\
Poorer & 7,515 & 19.29 \\
Middle & 8,001 & 20.54 \\
Richer & 8,450 & 21.70 \\
Richest & 8,380 & 21.52 \\
Absolute Poverty & & \\
Non Poor & 24,831 & 63.75 \\
Poor & 14,117 & 36.25 \\
\hline
\end{tabular}

Source: Authors' Computation, Using 2013 DHS

The overall evidence from table 2, 16.95 percent of the households are extremely poor. The statistic shows a difference of 21.75 percent in contrast to 38.7 percent of extreme poverty in Nigeria for 2010 as indicated in Nigeria's poverty profile report for the year (see National Bureau of Statistic, 2012). However, absolute poverty based on the dataset stood at 36.25 percent which indicates a difference of 24.65 percent in contrast to national absolute poverty of 60.9 percent as at 2010 (see National Bureau of Statistic, 2012). These differences may be mainly attributed to divergence of methodology used for collecting DHS 2013 and Nigeria's poverty profile for 2010.

Table 3: Summary Statistic of Age of Household Head and Household Size

\section{Distributions}

\begin{tabular}{|llllll|}
\hline Variable & Observation & Mean & Std. Dev & Minimum & Maximum \\
AgeHH & 38885 & 45.30138 & 13.90674 & 15 & 95 \\
HHSize & 38948 & 6.462411 & 3.706211 & 1 & 35 \\
\hline
\end{tabular}

Source: Authors' Computation, Using 2013 DHS

However, summary statistic of age of household head and household size are presented in table 3 . The table depicts that mean age of household head surveyed is 45 years which means that on average, most of the labor force are working class. The table also reveals that an average household has 6 members and maximum of 35 members respectively. The scenario clearly concurred with polygamous nature of African countries in general and Nigeria in particular as it is believe that larger families have more chances of managing vast farm land than small families.

In addition, estimates from logistic model presented in third column of table 4 shows that demographic variables, labor characteristics, and social factors are strong determinants of incidence of poverty in Nigeria. Evidence from the study supports our theoretical propositions as all the coefficients of the variables have expected signs. Demographic variables included in the model indicate that age square, and female headed household are found to have more likelihood of being poor at 5 percent and 1 percent level respectively. This depicted typical Nigerian scenario where an elder member of a household is expected to take care for the responsibilities of his/her younger ones. This 
implies that as individual becomes older there is a certain point at which his/her earned income (both labor and non-labor income) might not be sufficient enough to carter for his/her immediate family and hence being vulnerable to poverty. Also, increase conflicts and violence in Nigeria led to death of men which left a female to take responsibilities of the family and the gender-inequality in resource control lead to vulnerability of a female headed household to poverty.

Increase in households' size and age linear (though not statistically significant) are associated with less likelihood of becoming poor at 1 percent. This suggests that the number(s) of household members in a family or household induce their wellbeing positively as a result more number of family members will have a positive influence on socio-economic status of a given household. This result clearly supports African culture of polygamous family which aid in managing vast agricultural land and such families are less likely to be subjected to poverty and hunger as there is high tendency for large family to be landlords. This finding is consistent with the work of Anyanwu, (2010); Sakuhuni et al, (2011); and Deressa, (2013).

Table 4: Results of Socio-Demographic Determinants of Poverty in Nigeria

\begin{tabular}{|c|c|c|c|}
\hline Independent Variables & LPM (OLS) & $\begin{array}{l}\text { Ordered } \quad \text { Logistic } \\
\text { Model }\end{array}$ & Logistic Model \\
\hline \multicolumn{4}{|l|}{ Demographic Factors } \\
\hline AgeHH & $\begin{array}{l}-0.00131^{*} \\
(0.000738)\end{array}$ & $\begin{array}{l}0.0204 * * * \\
(0.00402)\end{array}$ & $\begin{array}{l}-0.00638 \\
(0.00629)\end{array}$ \\
\hline AgeHH2 & $\begin{array}{l}1.82 \mathrm{e}-05^{* *} \\
(7.31 \mathrm{e}-06)\end{array}$ & $\begin{array}{l}-0.000303 * * * \\
(4.00 \mathrm{e}-05)\end{array}$ & $\begin{array}{l}0.000125^{* *} \\
(6.23 \mathrm{e}-05)\end{array}$ \\
\hline HHSize & $\begin{array}{l}-0.00583 * * * \\
(0.000563)\end{array}$ & $\begin{array}{l}0.0144 * * * \\
(0.00306)\end{array}$ & $\begin{array}{l}-0.0317 * * * \\
(0.00445)\end{array}$ \\
\hline Female & $\begin{array}{l}-0.00238 \\
(0.00493)\end{array}$ & $\begin{array}{l}-0.337 * * * \\
(0.0270)\end{array}$ & $\begin{array}{l}0.125 * * * \\
(0.0448)\end{array}$ \\
\hline Labor Characteristics & & & \\
\hline Heduc & $\begin{array}{l}-0.0923 * * * \\
(0.00362)\end{array}$ & $\begin{array}{l}1.016 * * * \\
(0.0206)\end{array}$ & $\begin{array}{l}-0.818 * * * \\
(0.0316)\end{array}$ \\
\hline Employment & $\begin{array}{l}-0.00422 \\
(0.00377)\end{array}$ & $\begin{array}{l}0.0740 * * * \\
(0.0206)\end{array}$ & $\begin{array}{l}-0.00148 \\
(0.0322)\end{array}$ \\
\hline Literacy & $\begin{array}{l}-0.152 * * * \\
(0.00713)\end{array}$ & $\begin{array}{l}0.342 * * * \\
(0.0384)\end{array}$ & $\begin{array}{l}-0.527 * * * \\
(0.0554)\end{array}$ \\
\hline Social Characteristics & & & \\
\hline NE & $\begin{array}{l}0.361 * * * \\
(0.00691)\end{array}$ & $\begin{array}{l}-1.767 * * * \\
(0.0383)\end{array}$ & $\begin{array}{l}2.281 * * * \\
(0.0598)\end{array}$ \\
\hline NC & $\begin{array}{l}0.105^{* * * *} \\
(0.00654)\end{array}$ & $\begin{array}{l}-0.567 * * * \\
(0.0356)\end{array}$ & $\begin{array}{l}0.834 * * * \\
(0.0591)\end{array}$ \\
\hline NW & $\begin{array}{l}0.367 * * * \\
(0.00834)\end{array}$ & $\begin{array}{l}-1.826 * * * \\
(0.0459)\end{array}$ & $\begin{array}{l}2.322 * * * \\
(0.0709)\end{array}$ \\
\hline SE & $\begin{array}{l}0.168 * * * \\
(0.0121)\end{array}$ & $\begin{array}{l}-1.979 * * * \\
(0.0764)\end{array}$ & $\begin{array}{l}2.128 * * * \\
(0.160)\end{array}$ \\
\hline SW & $\begin{array}{l}0.137 * * * \\
(0.00880)\end{array}$ & $\begin{array}{l}-0.380 * * * \\
(0.0494)\end{array}$ & $\begin{array}{l}0.968 * * * \\
(0.0884)\end{array}$ \\
\hline
\end{tabular}




\begin{tabular}{|c|c|c|c|}
\hline \multirow{4}{*}{$\begin{array}{l}\text { Rural } \\
\text { Igbo }\end{array}$} & $0.266^{* * *}$ & $-2.062 * * *$ & $2.107 * * *$ \\
\hline & $(0.00422)$ & $(0.0249)$ & $(0.0378)$ \\
\hline & 0.00442 & $0.951 * * *$ & $-0.613 * * *$ \\
\hline & $(0.0110)$ & $(0.0705)$ & $(0.153)$ \\
\hline Hausa & $\begin{array}{l}-0.0323 * * * \\
(0.00679)\end{array}$ & $\begin{array}{l}0.376 * * * \\
(0.0367)\end{array}$ & $\begin{array}{l}-0.275 * * * \\
(0.0531)\end{array}$ \\
\hline Yoruba & $\begin{array}{l}-0.0587 * * * \\
(0.00817)\end{array}$ & $\begin{array}{l}0.379 * * * \\
(0.0457)\end{array}$ & $\begin{array}{l}-1.164 * * * \\
(0.0955)\end{array}$ \\
\hline Constant cut 1 & & $\begin{array}{l}-3.231 * * * \\
(0.103)\end{array}$ & \\
\hline Constant cut 2 & & $\begin{array}{l}-1.486^{* * * *} \\
(0.102)\end{array}$ & \\
\hline Constant cut 3 & & $\begin{array}{l}0.172 * \\
(0.102)\end{array}$ & \\
\hline Constant cut 4 & & $\begin{array}{l}2.034 * * * \\
(0.102)\end{array}$ & \\
\hline Constant & $\begin{array}{l}0.264 * * * \\
(0.0187)\end{array}$ & & $\begin{array}{l}-2.159 * * * \\
(0.161)\end{array}$ \\
\hline Observations & 38,483 & 38,483 & 38,483 \\
\hline R-squared & 0.469 & 0.2736 & 0.4378 \\
\hline
\end{tabular}

Source: Authors' Computation, Using 2013 (DHS)

Moreover, labor characteristics included in the model portray that incremental educational attainment, employment, and literate labor have less probability on chances of being poor (though coefficient of employment is not statistically significant) at 1 percent respectively. This means that skill labor (acquired through education and/or training) would earned more labor income than the unskilled labor and their socio-economic status must differed due to difference in income and the marginal income earned by skill labor can impact positively on their living condition while the unskilled labor might have zero or negative marginal income, hence, their living condition will be worse off. The result obtained from our study is consistent with the one conducted by Shirazi, (1995); Anyanwu, (2010); Sakuhuni et al, (2011); and Deressa, (2013).

Further, social characteristics of households equally indicate that households residing in rural areas have more tendencies of being poor than their urban counterparts. This indicates that rural areas in Nigeria are increasingly being deprived basic public goods provision and essential infrastructural facilities which will improve their living conditions positively. Similarly, households in all the five geo-political zones in Nigeria (i.e North East, North Central, North West, South East, and South West) have more tendencies of becoming poor than those in oil rich South-South Nigeria. This suggests that failure by successive regimes in the country to harness economic 
potentials in these geo-political zones subjected most households to abject poverty, in addition, the result implies that over dependence on crude petroleum does not augured well for majority of Nigerians. Finally the three major ethnic groups (Hausa, Igbo, and Yoruba) have less tendencies of being poor than any other minority ethnic groups in Nigeria at 1 percent respectively. This can be attributed to dominance of these major ethnic groups over minority ethnic groups in relation to socio-political and economic equations in the country. The finding is in consonant with the work carried out by Shirazi, (1995); Achia et al, (2010); and Anyanwu, (2010).

Nevertheless, the marginal effects of socio-demographic determinants of poverty in Nigeria were presented in table 5. Note that the first column presented marginal effects of socio-economic status of households (see regression result in second column of table 4) which also means for accuracy and consistency. Statistic from the table presented in second column shows that at a certain level of age (age control) the likelihood of becoming poor increases by 0.01 percent as a result of a year increased in the age of household head. Also, an increase in the number of household members by one person reduces the likelihood of being poor by 3.17 percent. A female headed household has 12.5 percent more likelihood of becoming poor than a household headed by a male.

Table 5: Marginal Effects of Socio-Demographic Determinants of Poverty in Nigeria

\begin{tabular}{|lll|}
\hline & Ordered Logistic Model & Logistic Model \\
Independent Variables & Base Outcome (5) dy/dx & Pr(Poor=1) dy/dx \\
AgeHH2 & $0.0204^{* * *}$ & -0.00638 \\
& $(0.00402)$ & $(0.00629)$ \\
HHSize & $-0.000303^{* * *}$ & $0.000125^{* *}$ \\
& $(4.00 \mathrm{e}-05)$ & $(6.23 \mathrm{e}-05)$ \\
Female & $0.0144 * * *$ & $-0.0317 * * *$ \\
& $(0.00306)$ & $(0.00445)$ \\
Labor Characteristics & $-0.337^{* * *}$ & $0.125^{* * *}$ \\
Heduc & $(0.0270)$ & $(0.0448)$ \\
& & \\
Employment & $1.016^{* * *}$ & $-0.818^{* * *}$ \\
& $(0.0206)$ & $(0.0316)$ \\
Literacy & $0.0740^{* * *}$ & -0.00148 \\
Social Characteristics & $(0.0206)$ & $(0.0322)$ \\
NE & $0.342^{* * *}$ & $-0.527 * * *$ \\
& $(0.0384)$ & $(0.0554)$ \\
NC & & \\
NW & $-1.767 * * *$ & $2.281^{* * *}$ \\
SE & $(0.0383)$ & $(0.0598)$ \\
& $-0.567 * * *$ & $0.834 * * *$ \\
& $(0.0356)$ & $(0.0591)$ \\
& $-1.826 * * *$ & $2.322^{* * *}$ \\
& $(0.0459)$ & $(0.0709)$ \\
& $-1.979 * * *$ & $2.128^{* * *}$ \\
\hline
\end{tabular}




\begin{tabular}{|lll|}
\hline SW & $(0.0764)$ & $(0.160)$ \\
Rural & $-0.380^{* * *}$ & $0.968^{* * *}$ \\
& $(0.0494)$ & $(0.0884)$ \\
Igbo & $-2.062^{* * *}$ & $2.107 * * *$ \\
& $(0.0249)$ & $(0.0378)$ \\
Hausa & $0.951^{* * *}$ & $-0.613 * * *$ \\
& $(0.0705)$ & $(0.153)$ \\
Yoruba & $0.376^{* * *}$ & $-0.275^{* * *}$ \\
& $(0.0367)$ & $(0.0531)$ \\
Constant cut1 & $0.379 * * *$ & $-1.164 * * *$ \\
& $(0.0457)$ & $(0.0955)$ \\
Constant cut2 & $-3.231^{* * *}$ & \\
Constant cut3 & $(0.103)$ & \\
Constant cut4 & $-1.486^{* * *}$ & \\
Constant & $(0.102)$ & \\
& $0.172^{*}$ & \\
Observations & $(0.102)$ & $-2.159 * * *$ \\
& $2.034 * * *$ & $(0.161)$ \\
& $(0.102)$ & 38,483 \\
\hline
\end{tabular}

Source: Authors' Computation, Using 2013 (DHS)

More so, increment in educational attainment has 81.8 percent less chances of being poor and a literate household head has 52.7 percent less chances of becoming poor than an illiterate headed household. This portrays that massive investment in human capital would go a long way in curving the rate of poverty and chronic hunger in the country.

Finally, households residing in North East, North Central, North West, South East, and South West have 228.1 percent, 83.4 percent, 232.2 percent, 212.8 percent, and 96.8 percent more probabilities of becoming poor than households residing in Niger-Delta (South-South). The scenario depicts how miserable life is in the non oil rich zones of the country especially in North Central, North East, and South-South. Also, Households dwelling in rural areas have 210.7 percent more probabilities of being poor than those residing in urban Nigeria. This suggests a wide disparity between dwellers of rural and urban areas in relation to socio-economic fortunes. Equally, households from Nigeria's major ethnic groups (Hausa, Igbo, and Yoruba) have 61.3 percent, 27.5 percent, and 116.4 percent less probabilities of becoming poor than households speaking other ethnic minority groups in the country respectively.

Table 6 presents Oaxaca-Blinder decomposition for socio-economic deprivation among female headed households and households headed by a male in Nigeria. The first column of the table shows that the average expected deprivation for female headed households is 40 percent while that of male 
headed households is 19 percent with a margin of 20.9 percent in favour of male headed households. This inequality in terms of socio-economic fortunes is accounted for by two major factors. These are overall endowments and overall interaction effects (as the overall coefficients effect is not significant). The total endowment effects revealed that there are some natural qualities peculiar to female headed households that need to be improved by 17.2 percent for them to have equal socio-economic opportunities with households headed by a male. Also, the joint effects of endowment and socio-demographic variables included in the model must be improved by 4 percent to achieve a balance in relation to resource control among households headed by female and male headed households in Nigeria.

However, the natural attributes (endowment effects) of individual variables is presented in second column of table 6 . The table indicates that age linear, level of educational attainment by household head, and a literate household head increase inequality in terms of socio-economic fortunes between households headed by female and male headed households by 0.06 percent, 4.53 percent, and 3.3 percent respectively. Households from NorthEast, North-West, and South-South, rural dwellers and those that speak Yoruba as their main language also increase the inequality in terms of socioeconomic fortunes between households headed by female and male headed households by 1.55 percent, 4.81 percent, 1.5 percent, 2.41 percent and 0.84 percent respectively. On the opposite, households from South-East, and those that speak Hausa as their major tribe narrow the difference (inequality) with respect to socio-economic fortunes between female headed households and households headed by male by 0.91 percent and 1.43 percent respectively.

Individual effects of the exogenous variables as presented in third column of table 6 suggest that households living in North-East, rural dwellers, and households that speak Igbo and Yoruba as their main tribe contributed to the inequality in terms of socio-economic fortunes between households headed by female and male headed households by 0.7 percent, 6.45 percent, 0.98 percent, and 1.08 percent respectively. On the other hand, household size, education qualification of household head, and South-East and South-South geo-political zones bridge the inequality in terms of socio-economic fortunes between households headed by female and male headed households in the country by 3.55 percent, 2.99 percent, 1.54 percent, and 1.07 percent respectively.

The interaction effects of both natural features of female headed households and exogenous variables as presented in the last column of table 6 show that household head educational attainment, households residing in North-East, South-East, and South-South zones as well as residence located at rural areas induce the difference (inequality) between female household head and male headed household with reference to inequality in socio-economic 
opportunities in the county by 1.05 percent, 0.91 percent, 0.79 percent, 0.57 percent and 2.08 percent. Conversely, household size, households that speak Igbo and Yoruba as their main language reduce the difference between female household head and male headed household with reference to socio-economic opportunities in the county by 1.96 percent, 0.47 percent, and 0.44 percent respectively.

Table 6: Oaxaca-Blinder Decomposition for Female-Male Socio-Economic Inequality in Nigeria, 2013

\begin{tabular}{|c|c|c|c|c|}
\hline & Total Effects & $\begin{array}{l}\text { Endowment } \\
\text { Effects }\end{array}$ & $\begin{array}{l}\text { Coefficient } \\
\text { Effects }\end{array}$ & $\begin{array}{l}\text { Interaction } \\
\text { Effects }\end{array}$ \\
\hline \multicolumn{5}{|l|}{ Independent } \\
\hline \multicolumn{5}{|l|}{ Variables } \\
\hline group1(Female) & $(0.00276)$ & & & \\
\hline \multirow[t]{2}{*}{ group2 (Male) } & $0.190 * * *$ & & & \\
\hline & $(0.00468)$ & & & \\
\hline Difference & $\begin{array}{l}0.209 * * * \\
(0.00544)\end{array}$ & & & \\
\hline Endowments & $\begin{array}{l}0.172 * * * \\
(0.00598)\end{array}$ & & & \\
\hline Coefficients & $\begin{array}{l}-0.00287 \\
(0.00497)\end{array}$ & & & \\
\hline Interaction & $\begin{array}{l}0.0400 * * * \\
(0.00574)\end{array}$ & & & \\
\hline AgeHН & & $\begin{array}{l}0.000632 * \\
(0.000374)\end{array}$ & $\begin{array}{l}0.00225 \\
(0.0143)\end{array}$ & $\begin{array}{l}6.53 \mathrm{e}-05 \\
(0.000415)\end{array}$ \\
\hline \multicolumn{5}{|l|}{ AgeHH2 } \\
\hline \multirow[t]{2}{*}{ HHSize } & & 0.00248 & $-0.0355 * * *$ & $-0.0196 * * *$ \\
\hline & & $(0.00404)$ & $(0.00775)$ & $(0.00430)$ \\
\hline \multirow[t]{2}{*}{ Heduc } & & $0.0453 * * *$ & $-0.0299 * *$ & $0.0105^{* *}$ \\
\hline & & (0.00458) & $(0.0146)$ & $(0.00511)$ \\
\hline Employment & & $\begin{array}{l}-5.32 \mathrm{e}-05 \\
(0.000225)\end{array}$ & $\begin{array}{l}-0.00393 \\
(0.00636)\end{array}$ & $\begin{array}{l}0.000153 \\
(0.000251)\end{array}$ \\
\hline \multirow[t]{2}{*}{ Literacy } & & $0.0330 * * *$ & -0.0193 & 0.00656 \\
\hline & & (0.00407) & $(0.0133)$ & $(0.00452)$ \\
\hline \multirow[t]{2}{*}{ NE } & & $0.0155 * * *$ & $0.00703 * * *$ & $0.00911 * * *$ \\
\hline & & $(0.00231)$ & (0.00194) & $(0.00251)$ \\
\hline \multirow[t]{2}{*}{ NC } & & -0.000166 & -0.00337 & -0.000355 \\
\hline & & $(0.000261)$ & $(0.00280)$ & $(0.000314)$ \\
\hline \multirow[t]{2}{*}{ NW } & & $0.0481 * * *$ & 0.000152 & 0.000427 \\
\hline & & $(0.00605)$ & $(0.00228)$ & $(0.00641)$ \\
\hline \multirow[t]{2}{*}{ SE } & & $-0.00907 * * *$ & $-0.0154 * * *$ & $0.00787 * * *$ \\
\hline & & $(0.00261)$ & $(0.00577)$ & $(0.00297)$ \\
\hline \multirow[t]{2}{*}{ SS } & & $0.0150 * * *$ & $-0.0107 * *$ & $0.00565^{*}$ \\
\hline & & $(0.00253)$ & $(0.00544)$ & (0.00288) \\
\hline \multirow[t]{2}{*}{ Rural } & & $0.0241 * * *$ & $0.0645 * * *$ & $0.0208 * * *$ \\
\hline & & $(0.00172)$ & $(0.00489)$ & (0.00179) \\
\hline Igbo & & 0.00330 & $0.00981 *$ & $-0.00469 *$ \\
\hline
\end{tabular}




\begin{tabular}{|llll|}
\hline Hausa & $(0.00244)$ & $(0.00586)$ & $(0.00281)$ \\
& $-0.0143 * * *$ & 0.00256 & 0.00792 \\
Yoruba & $(0.00544)$ & $(0.00183)$ & $(0.00564)$ \\
& $0.00835 * * *$ & $0.0108 * * *$ & $-0.00439 * * *$ \\
Constant & $(0.00149)$ & $(0.00404)$ & $(0.00166)$ \\
& & 0.0181 & \\
& & $(0.0272)$ & \\
Observations $\quad 38,483$ & 38,483 & 38,483 & 38,483 \\
$\begin{array}{l}\text { Note: Standard errors in parentheses. } \\
\text { and 10\% respectively }\end{array}$ & & \\
\hline
\end{tabular}

Source: Authors' Computation, Using 2013 (DHS)

\section{Conclusion and Policy Implications}

The findings of the study suggest that households' demographic characteristics strongly influence likelihood of becoming poor in Nigeria. To effectively reduce incidence of poverty in the country there is need for social insurance scheme targeting ageing population and the vulnerable groups (female headed households), and effective and sustain health care service delivery across both rural and urban Nigeria for enhancing and maintaining healthy labor force.

Secondly, dynamics of human capital is a crucial determinant of poverty in Nigeria given that chance of becoming poor reduces with increased educational attainment and literacy level, there is need therefore for government at all levels of governance in the country to review and restructure our curriculum with special emphasis given to technical courses/schools in order for the Nigerian economy to catch up with global technological drive.

Thirdly, social forces are equally strong variants that influence possibilities of being poor in Nigeria, as such there is urgent need for government to redirect its capital expenditure on infrastructures targeting regional balanced resource allocation, revisiting and revitalizing the country's potentials in agricultural, mining, and manufacturing sectors of the economy to address the ill-balance in terms of regional wellbeing, action plans on transformation of rural areas and attitudinal change among Nigerian households would correct or revert misfortunes of rural dwellers and the widening gap between major ethnic groups and minority ethnic groups in the country.

Finally, female headed households are found to be more likely suffered from socioeconomic deprivation relative to their male counterparts. This may be link to the fact that as the country is facing incessant ethno-religious and socio-political crisis that in most cases led to the lost of human capital (most of whom are male). The situation is confounded by the family settings in the country in which most households are predominantly polygamous as a result the spouse of the victims of these crisis automatically become the head. It is 
also worthy to note that female labor has certain limitation(s) in terms of resource control and/or choice for labor market participation. Hence, there is an urgent need for all stakeholders to redesign favorable labor policies that will enhance female participation in the organized labor market which in turn can revert their situation in relation to resource ownership and control.

\section{References:}

1. Abdullahi, M. I. (2014). An appraisal of the impact of MDGs on the eradication of poverty and extreme hunger in Nigeria. 55th Annual Nigerian Economics Society (NES) Conference from 7th-11th November, 2014. Abuja: Nigerian Economic Society (NES).

2. Achia, T. N., Wangombe, A., \& Khadioli, N. (2010). A logistic regression model to identify key determinants of poverty using Demographic and Health Survey data. European Journal of Social Sciences, 13(1), 38-45.

3. Adeola, F. O. (2005). Racial and class divergence in public attitudes and perceptions about poverty in USA: An empirical study. Race, Gender and Class, 12(2), 53-80.

4. Anyanwu, J. C. (2010). Poverty in Nigeria: A gendered analysis. The African Statistical Journal, 11:38-61.

5. Baum, C. F. (2006). An introduction to modern econometrics using Stata.Texas: StataCorp LP.

6. Blinder, A. S. (1973). Wage discrimination: Reduced form and structural estimations. The Journal of Human Resources, 8: 436-455.

7. Cameron, A. C., \& Trivedi, P. K. (2009). Microeconometrics using Stata. Texas: StataCorp LP.

8. Chadhry, I. S., \& Rahman, S. (2009). The impact of gender inequality in education on rural poverty in Pakistan: An empirical analysis. European Journal of Economics, Finanace and Administrative Sciences, 15, 174-188.

9. Chambers, R. (1995). Poverty and livelihoods: Whose reality counts? Environment and Urbanisation, 7(1), 173-204.

10. Chaudhry, I. S., Malik, S. W., \& Ashraf, M. (2006). Rural poverty in Pakistan: Some related concepts, issues and empirical analysis. Pakistan Economic and Social Review 44(2), 259-276.

11. Christiaensen, L., Demery, L., \& Pasternostro, S. (2003). Macro and micro perspectives of growth and poverty in Africa. The Wolrd Bank Economic Review 17(13), 317-347.

12. Collier, P. (2007). Poverty reduction in Africa. Proceedings of the National Academy of Sciences of the United States of America 104(43), 16763-16768. 
13. Dasgupta, R. (1982). A cross-sectional analysis of poverty and undernutrition in rural India. Economic and Political Weekly, 17(39), 1575-1578.

14. Deressa, D. F. (2013). Assessing households vulnerability to poverty in rural Oromiya-Ethiopia. Journal of Economic and Sustainable Development 4(8), 110-117.

15. Dollar, D., \& Kraay, A. (2002). Growth is good for the poor. Forthcoming: Journal of Economic Growth.

16. Fields, G. S. (1989). Changes in poverty and inequality in developing countries. The Wolrd Bank Research Observer 4(2), 167-185.

17. Figini, P., \& Santarelli, E. (2006). Oppeness, economic reforms, and poverty: Globalisation in developing countries. The Journal of Developing Areas, 39(2), 129-151.

18. Foster, J., Greer, J., \& Thorbecke, E. (1984). A class of decomposable poverty measures. Econometrica, 52: 761-5.

19. Greene, W. H. (2013). Econometric Analysis, 5th Edition. New York: Pearson Education, Inc.

20. Guiga, H., \& Rejeb, J. B. (2012). Poverty, growth and inequality in developing countries. International Journal of Economics and Financial Issues 2(4), 470-479.

21. Hunte, C. K. (1997). Poverty alleviation indicators: Empirical evidence from ninty-five countries. Savings and Development 21(1), 35-48.

22. Ijaiya, G. T., Ijaiya, M. M., Bello, R. A., \& Ajayi, M. A. (2011). Economic growth and poverty reduction in Nigeria. International Journal of Business and Social Sciences, 2(15), 147-154.

23. Iyenda, G. (2007). Researching rural poverty in Sub-Saharan Africa. Development in Practice, 17(1), 27-38.

24. Kodras, J. E. (1997). The changing map of American poverty in an era of economic restructuring and political realignment. Economic Geography, 73(1), 67-93.

25. Maku, O. E., Ogwumike, F. O., \& Adesoye, A. B. (2014). Sub-Saharan Africa (SSA) and the millenium development goals (MDGs): Performance and strategic options. 55th Annual Nigerian Economics Society (NES) Conference from 7th-11th November, 2014. Abuja: Nigerian Economics Society (NES).

26. McNamara, R. S. (1975). Urban poverty in developing countries: A World Bank analysis. Populationa nd Development Review, 1(2), 339349.

27. Mowafi, M., \& Khawaja, M. (2005). Poverty. Journal of Epidemiology and Community Health, 59(4), 260-264. 
28. National Bureau of Statistic. (2012). The Nigerian poverty profile 2010 report. Abuja: National Bureau of Statistic.

29. National Population Commission (NPC) [Nigeria] \& ICF International. (2014). Nigeria Demographic and Health Survey 2013. Abuja, Nigeria, Rockville, Maryland, USA: NPC and ICF International.

30. Neilson, C., Contreras, D., Cooper, R., \& Hermann, J. (2008). The dynamics of poverty in Chile. Journal of Latin American Studies, 40(2), 251-273.

31. Oaxaca, R. (1973). Male-female wage differentials in urban labor markets. International Economic Review, 14: 693-709.

32. Sakuhuni, R. C., Chidoko, C., Dhoro, N. L., \& Gwaindepi, C. (2011). Economic determinants of poverty in Zimbabwe. International Journal of Economic Research, 2(6) , 1-12.

33. SESRTCIC. (2007). Poverty in Sub-saharan Africa: The situation in the OIC member countries. A prelimenary report.

34. Shirazi, N. S. (1995). Determinants of poverty in Pakistan. Pakistan Economic and Social Review 33(1), 91-101.

35. Skalli, L. H. (2001). Women and poverty in Morocco: The many faces on social exclusion. Feminist Review, 69:73-89.

36. Stephen, B. A., \& Simeon, I. A. (2013). Does economic growth reduce poverty in Nigeria? Developing Country Studies 3(9), 62-68.

37. Thurow, L. C. (1967). The causes of poverty. The Quaterly Journal of Economics 81(1), 39-57.

38. Todaro, M. P., \& Smith, S. C. (2011). Economic Development, 11th $E d$. Harlow: Pearson Education Limited.

39. Ucha, C. (2010). Poverty in Nigeria: Some dimensions and contributing factors. Global Majority E-Journal, 1(1), 46-56.

40. United Nations. (2015). Open working group proposal for Sustainable Development Goals (SDGs). United Nations Department of Economic and Social Affairs. Retrieved Monday, October 12, 2015 from https://sustainabledevelopment.un.org/focussdgs.html

41. Wooldridge, J. M. (2002). Econometric Analysis of Cross-Section and Panel Data. Cambridge: The MIT Press. 